\title{
Primary Schools Online Learning Strategies in COVID-19 Era
}

\author{
Windari ${ }^{1,{ }^{*}}$ Rosmala Dewi ${ }^{2}$ Rosnelli ${ }^{3}$ Din Oloan Sihotang ${ }^{4}$ Johannes Sohirimon
}

\author{
Lumban Batu
}

\author{
${ }^{1}$ Postgraduate School in Education Management Program Universitas Negeri Medan North Sumatra, Indonesia \\ ${ }^{2,3}$ Postgraduate School Universitas Negeri Medan North Sumatra, Indonesia \\ ${ }^{4,5}$ STP St. Bonaventura Keuskupan Agung Medan North Sumatra, Indonesia \\ *Corresponding author. Email: windari17031976@gmail.com
}

\begin{abstract}
Although many research results discuss the problems of learning education during the COVID 19 pandemic, there has been no more specific and comprehensive research in discussing alternative strategies in online learning in primary schools during the COVID 19 pandemic. This paper seeks to provide a theoretical basis for alternative learning strategies that be used as a reference for elementary school teachers in learning online. The research conducted at elementary schools that domiciled in the city of Medan. The type of research in this paper is library research, with a conceptual approach and a comparative approach. The results of this study indicate that there are four strategies that are very relevant to be used in online learning in elementary schools during the COVID-19 pandemic, namely: 1) Guided Inquiry Learning, 2). Contextual Teaching Learning. 3) Problem Based Learning, and, 4) Student Active Learning. Of the four strategies, the teacher can choose one strategy that suits the type of material presented by prioritizing student needs.
\end{abstract}

Keywords: online, learning, strategies, COVID-19.

\section{INTRODUCTION}

The COVID-19 pandemic has caused many significant influences and changes in various aspects that surround human life, so that all are required to respond quickly, in order to find solutions to the changes that occurred [1] After Corona became an epidemic (pandemic) in Indonesia at the beginning from March 2020 until now, the government has made various policies to deal with and overcome the COVID-19 pandemic, such as: (1) staying at home; (2) Social Distancing; (3) Physical Distancing; (4) Use of Personal Protective Equipment (Masks); (5) Maintaining Personal Hygiene (Washing Hands); (6) Work and Study from Home 2 ; (7) Postpone all activities that gather large crowds; (8) Large-Scale Social Restrictions or PSBB; until the last, (9) the implementation of the New Normal [Darwin Tutu].

The biggest impact of the COVID-19 pandemic that was felt by the world of education in Indonesia was the policy to change the learning system from offline to online. This policy is an implementation of the Circular Letter of the Minister of Education and Culture Number
3 of 2020 concerning Prevention of COVID-19 in Education Units, and Circular Letter Number 4 of 2020 concerning the Implementation of Educational Policies in the Emergency Period of the Spread of Coronavirus Disease (COVID-19) [2].

In general, there are two impacts on the sustainability of education caused by the COVID-19 pandemic [3]. The first is the short-term impact. This impact is in the form of a psychological burden that must be borne by teachers, students, and parents. This is a big surprise for teachers because they have to reformulate existing learning tools, both from strategies, methods, and media, to evaluations that are in accordance with online learning and can meet well-defined learning objectives. For parents, especially those who are usually busy with their work outside the home, accompanying their children to carry out the online learning process is an additional burden. Likewise, with the psychological problems of students who are used to learning face to face with teachers and classmates, but must get used to learning independently through various media that they do not fully understand. For teachers, as the main key to success in learning, online learning has a more complex impact. Changes in the learning system 
very quickly force them to be able to prepare learning tools with strategies that suit their needs. Teachers are required to improve their ability in mastering learning materials, methods, and media in order to achieve the educational goals that have been determined [4].

The second is the long term impact. Many community groups in Indonesia will be exposed to the long-term impact of COVID-19. The long-term impact of education is the aspect of justice and increasing inequality between community groups and between regions in Indonesia. The unpreparedness of implementing online education, if not handled properly, can result in a decline in the quality of education and the graduates produced.

In addition to the above impacts, the continuity of online learning until now has caused many problems for parents, students and teachers because they are not used to learning online. Problems that are often found in online learning systems include limited mastery of information technology by teachers and students, inadequate facilities and infrastructure, limited internet access, and the unpreparedness of budget provision, and most importantly, student attendance that is difficult to control, attendance rate much decreased due to various factors including factors within students and less than optimal parental control. So that online learning is considered less effective and interactive compared to offline learning [5].

This paper attempts to provide a theoretical basis for alternative learning strategies that can be used as a reference for educators in conducting online Islamic Education Learning or in Bahasa is Pendidikan Agama Islam (PAI). The researcher tries to make an inventory of various literatures, especially journals related to this research, to be used as a reference. For this reason, researchers have conducted a literature review of various previous literatures that examine online PAI learning methods, some of which are journals with the title Implementation of e-learning on PAI subjects during the COVID-19 pandemic, which explains the obstacles experienced by students, teachers and parents. in online teaching and learning activities [6]. Journal with the title of online learning based on Google form media in response to work from home during the COVID 19 pandemic at Madrasah Ibtidaiyah 1 Paser, which explains about that teachers during WFH using Google forms as an educational space and online learning task bag [7]. Journal with the title Internalization of the value of independent learning in PAI learning during the COVID 19 pandemic, which explains the internalization of the value of independent learning in PAI learning during the COVID 19 pandemic which was implemented at SDN Rejosari 3 [8]. Journal with the title of using online media in PAI teaching and learning activities during the COVID 19 pandemic, which explains the use of online media in PAI KBM during the COVID 19 pandemic [9].

In the learning strategy there are three important components as follows: 1) Learning objectives that contain competencies that are expected to be achieved by students at the end of learning. 2) Content or learning materials in an order that corresponds to the sequence of learning objectives. 3) An approach in managing learning that involves a sequence of learning activities and a launch system which is the integration of methods, media, and tools, as well as the allocation of learning time [10]. From this understanding, it can be understood that learning strategies are closely related to several elements that must be important, including the selection of methods, models and learning media.

In the application of learning methods and models, it is necessary to have supportive learning media. Learning media can be interpreted as everything that is used to convey messages (knowledge, skills, and attitudes) and can stimulate the thoughts, feelings, attention and willingness of students so that the learning process occurs intentionally, purposefully and in control [11]. The form of online learning media that can be used in PAI learning is electronic media that utilizes technology. The easiest media for students to operate is a smart phone that has supporting applications including WhatsApp, YouTube, Lite Facebook, Email, group meeting applications (zoom, Google meet, cloudX and others), Google classroom, google forms and so on. You can also use existing online learning applications such as: Ruang Guru, Sekolahmu, Icando, Rumah Belajar, Meja Kita, IndonesiaX, Google for Education, Kelas Pintar, Zenius and so on.

\section{THEORETICAL DESCRIPTION}

\subsection{Industrial Revolution 4,0 Basic Concepts of Learning Strategies}

The term "strategy" implies a general pattern of activities that are planned to carry out an activity, which involves many elements that must be regulated. Strategy in education has been known as 'learning strategy'. Related to learning activities, the term strategy implies the general pattern set by a teacher in carrying out learning activities to be carried out [12], [5]. The formulation according to [12] explains that learning strategies are a collection of one or more procedures needed by students to facilitate student learning abilities. The intended procedure is the stages that must be passed so that the learning objectives are achieved. Thus the strategy shows the steps of activities or procedures used in presenting teaching materials to achieve goals, competencies, and learning outcomes [6]. The term learning strategy covers various aspects of choosing a launch system, sorting, and grouping learning content, explaining the learning components that will be included in learning, determining how to group students during learning, creating lesson structures, and selecting media to launch learning [13]. This means that the strategy is basically still conceptual about the decisions that will be 
taken in an implementation of learning. Judging from the strategy, learning can be grouped into two parts, namely: 1) exposition-discovery learning and 2) group-individual learning. Judging from the way it is presented and how it is processed, learning strategies can be distinguished between inductive learning strategies and deductive learning strategies [14].

\subsection{Islamic Religious Education Learning}

Learning from the point of view of cognitive theory, is defined as a learning process built by teachers to develop creative thinking that can improve students' ability to construct new knowledge as an effort to increase good mastery of the subject matter. Based on this understanding, learning can be said as a teacher's effort to provide stimulus, direction and encouragement to students so that the learning process occurs [15]. According to [16] learning is a relatively permanent change in students' abilities, attitudes, or behaviour as a result of experience or training. According to UUSPN number 20 of 2003, learning is a process of interaction between students and educators and learning resources in a learning environment. There are five concepts in this sense, namely: (1) interaction, (2) students, (3) educators, (4) learning resources, and (5) learning environment. The main characteristic of learning is the initiation, facilitation, and improvement of the student learning process [16].

\section{METHOD}

This paper is the result of library research. This type of library research is research that relies almost entirely on data from the literature or literature, both in physical and digital form. The approach used is a conceptual approach, and a comparative approach. The concept approach is carried out until an effort to improve and a new approach is found to overcome the existing problems. While comparative is a type of descriptive research that wants to find answers in a fundamental way about cause and effect, by analysing the factors that cause the occurrence or emergence of a certain phenomenon. So comparative research is a type of research that is used to compare between two or more groups of a certain variable [17].

\section{RESULT AND DISCUSSION}

In choosing a strategy that is appropriate and can really answer the challenges of PAI online learning in the pandemic era, it is very important for a teacher to understand the characteristics of the material to be delivered. And as a good teacher, the teacher should continue to establish effective communication with all his students even within the limitations of space and time. The teacher's teaching task will be successful when the teacher can perform optimally in carrying out his duties [18]. Mastery of the material, attractive appearance, utilization of methods and media, as well as various prerequisites for teaching success must still receive adequate attention from the teacher, although not in the normal learning process as usual. Accuracy in the use of approaches, strategies, and methods during learning activities will determine the creation of conducive and pleasant conditions so as to provide opportunities for students to gain convenience in studying the knowledge material presented. Through this condition, various forms of interaction that are built will be able to facilitate the process of students to gain learning experiences in order to develop their abilities (i.e. spiritual, mental: intellectual, emotional, social, and physical (senses) conducive, then there are several criteria in determining the choice of approaches, strategies, and methods to be used, namely: 1. Competencies to be achieved through learners, 2. Knowledge materials to be presented through learners, 3. Characteristics of learners.

In this online learning process, not all types of learning strategies can be applied in the PAI learning process. Some appropriate alternative strategies to achieve PAI learning objectives include the following;

\subsection{Discovery/Inquiry Learning}

One of the learning models to develop cognitive and socio emotional aspects of school-age children is the cognitive instructional model initiated by Bruner, known as discovery learning. One model of discovery learning is inquiry formatted by Dewey and has been adapted in various forms or strategies [18]. The Discovery/Inquiry Learning Strategy is a learning strategy that focuses on searching and finding activities for students themselves [14].

Use one of the most relevant forms of inquiry in online PAI learning is guided inquiry. Guided inquiry is oriented to student-cantered activities and allows students to learn to utilize various learning resources that do not only make the teacher a learning resource. In this strategy, the teacher asks questions or expresses dilemmas that require solutions, provides appropriate materials and interesting, and improve students' ability to express and test hypotheses. In a row, the guided inquiry steps are as follows:

a. There is a problem be solved, which is stated in a question or statement.

b. Clear level/class.

c. The concepts or principles that students must discover through these activities need written clearly.

d. Tools/materials need provided according to the needs of students in carrying out activities.

e. Discussion as a direction before students carry out activities.

f. The activity of the discovery method by students is in the form of an investigation/experiment to 
find the concepts or principles that have been set.

g. The critical thinking process needs to be explained to show the students' operational mentality, which is expected in the activity.

h. It is necessary to develop open-ended questions, which lead to activities carried out by students.

i. There is a teacher's note which includes an explanation of difficult matters and factors that can affect the results, especially if the investigation fails or does not go as it should.

\subsection{Contextual Teaching Learning}

Contextual Teaching Learning (CTL) is a learning strategy that emphasizes the process of full student involvement to find the studied material and relate it to real-life situations. CTL learning is learning that uses a variety of contextual problems as a starting point, so that students learn by using their knowledge and abilities to solve problems, both real problems and simulation problems, both problems related to other lessons in school, school situations, and problems outside of school, including relevant workplace problems [14]. The CTL approach is a learning concept that helps teachers relate the taught material to students' real world situations and encourages students to make connections between their knowledge and its application in their lives [4].

This CTL strategy used in most PAI material delivery, especially on morals material. Students' daily activities at home are the implications of morals material in PAI learning. Therefore, it is very easy for teachers to direct students to do contextual learning during online situations like this. Students are also more flexible in using internet media to find other facts that are more relevant to learning.

\subsection{Problem Based Learning}

Problem Based Learning (PBL) is a problem-cantered learning activity. The term cantered means to be the theme, unit, or content as the focus of learning.

The most appropriate method in the PBL strategy is the use of problem solving methods. The steps of the problem solving method are as follows:

a. There is a clear problem to solve. This problem must grow from students according to their abilities.

b. Looking for data or information that can be used to solve the problem. For example, by reading books, discussing, researching, and asking questions and others. c. Establish a temporary answer to the problem. This alleged answer is of course based on the data that has been obtained in the second step.

d. Test the correctness of the temporary answer. In this step students must try to solve the problem so that they are really sure if the answer is correct.

e. Draw a final conclusion about the answer to the problem.

In PAI online learning, this PBL strategy is very effective in training active students as social observers. Teachers can direct students to observe social problems that exist around them. Then based on the results of these observations, the teacher guides students to formulate questions related to the material being studied. This PBL strategy is very appropriate for materials related to morality, because the problems that arise related to these materials are many and varied.

\subsection{Student Active Learning}

As a form of learning strategy, the application of SAL in learning has very broad implications, both for the roles and tasks of teachers and students, the learning environment developed, the facilities and infrastructure prepared, and especially on the sequence of activities that must be carried out by students. The role and task of the teacher in implementing the SAL learning strategy is as a facilitator. The teacher is tasked with creating a conducive "classroom" environment, which allows students to flexibly carry out various activities, both physical and especially mental and emotional activities. The provision of diverse learning resources allows students to carry out varied learning activities. Stimulation in the form of problems that challenge higher-order thinking must be formulated and conveyed to students. Therefore, to implement this strategy, it must start from planning, which is continued in the learning process, as well as its evaluation [3].

A number of methods that allow learning that apply student active learning strategies include discussion, experiment, simulation, demonstration, practice/practice, and inquiry/discovery methods. The application of the SAL strategy in PAI online learning is very flexible in all types of materials and situations. Because this strategy is very appropriate to be used in training students' independent learning. Especially on PAI materials related to worship and "Muamalah" practices, such as ablution, prayer, "Tayammum", buying and selling and others using practical and simulation ethos. Teachers can use video media to make it easier for students to understand the material, as well as media for teacher evaluation of student learning outcomes. 


\section{CONCLUSION}

Success in achieving the goals of PAI is partly due to the ability of a teacher to prepare appropriate learning strategies. The maturity of the preparation of learning methods, models and media is one of the main factors that can help improve learning outcomes. Thus, to achieve PAI learning objectives in this online learning period, the selection of learning strategies by teachers needs to pay attention to the characteristics and needs of students in accordance with the related material, and it is very necessary to have learning strategies that arranged systematically and attractively so that they can achieve the expected competencies.

Some relevant learning strategies used in online learning of Islamic Religious Education include: 1) Guided Inquiry. Use this guided inquiry strategy in learning abstract Aqidah material, which requires critical thinking and evidence to understand the material to foster strong beliefs in the hearts and minds of students. 2) Contextual Teaching Learning (CTL). This CTL strategy used in most PAI material delivery, especially on Muamalah and morals material, because students' daily activities at home closely related to the application of moral and Muamalah material content in PAI learning. Therefore, it is very easy for teachers to direct students to do contextual learning during online situations like this. 3) Problem Based Learning. This PBL strategy is very appropriate for materials related to morality and Muamalah, because the problems that arise related to these materials are many and varied. 4) Student Active Learning. The SAL strategy is in accordance with all types of PAI material, especially on worship and Muamalah practice materials by utilizing practical and simulation methods.

\section{REFERENCES}

[1] Susilo, Adityo et al. (2020). "Skoring Yang Digunakan Dalam Penanganan COVID-19." 7(1): 68-77.

[2] Ahmad, Iqbal Faza. (2020). "Asesmen Alternatif Dalam Pembelajaran Jarak Jauh Pada Masa Darurat Penyebaran Coronavirus Disease (Covid-19) Di Indonesia." PEDAGOGIK: Jurnal Pendidikan 7(1): 195-222.

[3] Rizqon Halal Syah Aji. (2020). Dampak COVID-19 pada Pendidikan di Indonesia: Sekolah, Keterampilan, dan Proses Pembelajaran. Jurnal Sosial \& Budaya Syar-i FSH UIN Syarif Hidayatullah Jakarta Vol. 7 No. 5

[4] Lumbanbatu J.S; et al. (2019). Policy Analysis Implementation of 2013 Thematic Learning Curriculum. 4th Annual International Seminar on Transformative Education and Educational Leadership (AISTEEL 2019), 384, 179-183.
[5] Sipayung, R., et al. (2021). PERSEPSI GURU TERHADAP EFEKTIVITAS PEMBELAJARAN ONLINE DI MASA PANDEMI COVID-19. 2, 311-321.

[6] Riska Syahfitri, dkk. (2020). Implementasi ELearning Pada Mata Pelajaran Pendidikan Agama Islam Dimasa Pandemi Covid-19. Al-Ulum Jurnal Pendidikan Islam Vol. 1, N0. 1.

[7] Sri Bulan dan Husniyatus. (2020). Pembelajaran Online Berbasis Media Google Formulir Dalam Tanggap Work From Home Masa Pandemi Covid19 Di Madrasah Ibtidaiyah Negeri (MIN) 1 Paser. Syamil Jurnal Pendidikan Agama Islam/Journal of Islamic Education. Volume 8. Nomor 1.

[8] Ranu Suntoro dan Hendro Widoro. (2020). Internalisasi Nilai Merdeka Belajar Dalam Pembelajaran PAI Di Masa Pandemi Covid-19. (Jurnal MUDARRISUNA Vol. 10 No. 2.

[9] Ahmad Jaelani, dkk. (2020). Penggunaan Media Online Dalam Proses Kegiatan Belajar Mengajar PAI Dimasa Pandemi Covid-19. Jurnal IKA: Ikatan Alumni PGSD UNARS Vol. 8 No. 1.

[10] Sapuadi. (2019). Strategi Pembelajaran. Medan: Harapan Cerdas

[11] Sihotang, D. O. (2019). OPTIMALISASI PENGGUNAAN GOOGLE CLASS ROOM DALAM PENINGKATAN MINAT BELAJAR BAHASA INGGRIS SISWA DI ERA REVOLUSI INDUSTRI 4.0 (Studi Kasus di SMK Swasta Arina Sidikalang). Jurnal Teknologi Kesehatan Dan Ilmu Sosial (Tekesnos), 1(1), 77-81. http://e-journal.sarimutiara.ac.id/index.php/tekesnos/article/view/981

[12] Sumantri, M. S. (2015). Strategi Pembelajaran Teori dan Praktik di Tingkat Pendidikan Dasar. Jakarta: Rajawali Pers

[13] Imanuel (2017). Strategi Pembelajaran, Tinjauan Umum Bagi Pendidik. Sintang: Penerbit STKIP Persada Khatulistiwa.

[14] Windari, et al (2020). Become a Professional Teacher in the Future. Proceedings of the 5th Annual International Seminar on Transformative Education and Educational Leadership (AISTEEL 2020), 488(Aisteel), 214-218. https://doi.org/10.2991/assehr.k.201124.046.

[15] Nurdyansyah dan Eni F Fahyun (2016). Inovasi Model Pembelajaran Sesuai Kurikulum 2013. Sidoarjo: Nizamia Learning Center

[16] Sri Haryati. (2017). Belajar dan Pembelajaran Berbasis Cooperative Learning. Magelang: Graha Cendekia 
[17] Nazir. (2005). Metode Penelitian. Jakarta: Ghalia Indonesia

[18] Ngainun Naim (2011). Dasar-Dasar Komunikasi Pendidikan. Sleman: Ar-Ruzz Media

[19] Sitorus, I. S., Sihotang, D. O., et al (2020). Competency Planning Strategies of Junior High School Teachers in increasing competitiveness. The 5th Annual International Seminar on Transformative Education and Educational Leadership (AISTEEL 2020), 488(Aisteel), 236241. https://doi.org/10.2991/assehr.k.201124.050 